\title{
レヒラーの「教本」における方立てとシャフトの設計法 DESIGN METHOD OF MULLIONS AND SHAFTS IN LECHLER'S "UNTERWEISUNG"
}

\author{
谷川 康 信* \\ Yasunobu TANIGAWA
}

\begin{abstract}
Lorenz Lechler, "Baumeister" in Heidelberg in the later Middle Ages, writes "Unterweisung" for his son.

This paper analyzed the design method of the templates of the architectural elements in this book. He instructs to design the templates of two sizes-"alt" (old, large) and "jung" (young, small) - as in the ratio $7: 5$ by the following means:
\end{abstract}

(1) The scheme consisted three inscribed squares that has the sides as in the ratio $10: 7: 5$.

(2) Two scales that is in the ratio $7: 5$.

Keywords : Lorenz Lechler, Unterweisung, inscribed squares, scale, ad quadratum, geometrical scheme

ローレンツ・レヒラー, 教本, 内接正方形, ものさし, 四角法, 幾何図式

序

15 世紀末から 16 世紀初にかけて活動したハイデルベ ルク出身の石工工匠ローレンッ・レヒラー (Lorenz Lechler, “Lacher”とつづられることもある) は，いく つかの教会堂の建設工事に記録されているものの，むし ろその名前は, 1516 年に『教本』 (Unterweisung) と よばれる本を書きのこしたことで知られる1”。教本」は, 教会堂建設にかかわるさまざまな寸法の決定方法を息子 のモーリッツに教示することを目的として書かれた。扱 われる寸法は, 教会堂の長さや幅などの建設全体に関す る大きな寸法と，方立て (参考図参照) や交差リブなど の各種の建築部分のテンプレート ${ }^{21}$ という比較的小さな 部分の設計に関するものに大別される。これらが文章に よって，またいくつかの部分については図を併用して説 明されている。

レヒラーの「教本』からほぼ 30 年さかのぼるころ, ドイツの建築工匠マテス・ロリッァーと, 金細工師ハン ス・シュムッテルマイアはそれぞれ小冊子一現在『ピナ クルに関する小冊子」(Buchlein von der Fialen Gerechtigkeit) という同じ名でよばれる一を書き，た だ一つの正方形からピナクルおよびその他の建築部分を 決定する方法を公開していた ${ }^{3 !}$ 。レヒラーの【教本】の なかの各種建築部分のテンプレートの設計を扱った部分
には,このロリッァーとシュムッテルマイアが明らかに した正方形を用いた形態決定方法 (「四角法」, ad quadratum) との類似点がみられ，その部分の考察から， 「四角法」, 延いてはゴシックの幾何図式につながりうる 知見を得ることができると思われる。

\section{1.『教本」の経緯と研究}

『教本」のテキストの経緯に関しては，シェルビー一 マークが詳しく報告している4)。彼らによると、『教本』 のオリジナル手稿は現存せず，二つの 16 世紀末の複製 が残されているのみである。一つはヤーコプ・フォイヒ ト・フォン・アンデルナッハ (Jacob Feucht von Andernach) によるもので, 現在ケルンの歴史文書館 (Historisches Archiv) に “Handschrift Wf. 276" と して保存されている。これは，1856 年にアウグスト・・ ライヘンシュペルガー (August Reichensperger)によっ て書きなおされた (transliterated) テキストとともに印 刷されている。他の一つは最近明らかになったもので, 1600 年ころ姓名不詳の写本家によってスイスのベルン でつくられた手稿である。これは現在八イデルベルク大 学図書館に “Hs. 3858” として分類されている。二つの 手稿は多くの共通する語句をもつが, 術語, 語順, 設計 法の技術的な細部に差異がみられる，という5”。

本稿は, 1990 年 2 月日本建築学会近畿支部研究報告集および 1990 年 10 月日本建築学会大会学術講演梗概集（中国）に発表したものをもとに加筆, 再編 したものである。

*大阪工業技術専門学校建築学科 講師· 工修

Lecturer, Dept. of Architecture, Osaka College of Technology, M. Eng. 
シェルビーーマーク自身は，上記論文は両手稿あるい はそれら互いのあいだに属する多くの技術的な問題を分 類する意図をもたず，これらの点はシェルビーが準備中 の校訂本において検討される予定というが6)，これは筆 者の知るかぎり未刊行である。また『教本』の文章につ いて十分な批評校訂がなされた他の研究も未だ刊行され ていないようである。本稿において図形を扱った部分に 対象を絞ったのはそのためもある。

なお本研究にあたって, レヒラーの上記二種の手稿の いずれも入手することができなかったため，主に以下の 四編の論考を参考にし，レヒラーの文章はこの四編中に あげられているものを使用した。レヒラーの文章の引用 に際しては, 著者がいずれの版を使用しているかを明記 しているものについてのみそれを括弧内に示した。明記 されていないものについても, 各著者の使用文献 (後述) から推定が可能である。

まず，上に引用した歴史家シェルビーと技術者マーク の協力になる論文であるが，これは構造技術・力学面か らの分析である。分析対象は，レヒラーが指示する建物 全体にかかわる設計法一たとえば，レヒラーが記述する 規模によく似た実際の教会堂との比較検討がなされる一 から, 壁やバットレス, そしてヴォールトといった建築 部分のテンプレートの設計法までを含む。しかしここで は本稿で検討対象とした, 正方形を組み合わせた八芒星 形の使用による各種建築部分の設計法に関する細かな分 析は行われていない。

シェルビーはまた，彼単独で著した論文》においてレ ヒラーをとりあげている。これはテンプレートを扱った ものであるので，レヒラーによる各種建築部分の設計法 が検討され，とくに本稿でとりあげた図一 3 に対する分 析は詳しい。ここでシェルビーは，レヒラーのテキスト としてケルン市立文書館所蔵の版と，これをわずかに書 きなおしたとするライヘンシュペルガーの版をあわせて 用いている（彼は引用に際し, ケルン版の引用ページ数 字のうしろの丸括弧内にライヘンシュペルガーの該当 ページを入れている)。

コンラート・ヘヒトは, ゴシックの教会堂と, 現存す るゴシック期の諸資料（ヴィラール，ロリッァー等）を 対象とし，ゴシック建築の設計法 (寸法, 形態決定) の 分析を内容とする著 ${ }^{8}$ のなかでレヒラーをとりあげてい る。ここで彼は，『教本』の複雑な構成一「文書におけ る主題の扱い方は非体系的であって，ある主題に関する 文章は『教本』のあちらこちらに散在しており，同じ主 題に関する記述を拾い集めるために『教本』のなかを戻っ たり進んだりする必要がある゙」といわれる一の全体を よく整理し解説を加えている。たとえば彼は，「教本」 における内陣の内法寸法加建築部分に至る多梯な寸法 が算出される過程をわかりやすく示す。また，方立てや
ヴォールト等の建築部分の設計法に関する詳細な分析も 行なっている。なおへヒトの本には，シェルビー一マー クが紹介したハイデルベルク大学図書館蔵の版に関する 言及が一切みられないこと，またへヒトの本には，フォ イヒト版を書きなおしたライヘンシュペルガー版に対す る研究者の批判一ライヘンシュペルガーが書きなおしを するに際して彼の恣意的な解釈が入っているとする一や 弁護が紹介されているものの，ライヘンシュペルガー版 に対してへヒト自身が疑義を呈していることなどから， ヘヒトはレヒラーの文章の出典としてフォイヒト版 (ケ ルン市立文書館所蔵）を使用していると思われる。

ポール・フランクルは, 広くゴシック建築を扱った 書 $^{(0)}$ において,レヒラーに関する簡単な紹介をしている。 そのため,『教本』中の図や文章は個別にとりあげられ て検討されているわけではない。フランクルは,レヒラー のテキストはライヘンシュペルガーによって出版された と述べているところから, 彼が数か所あげるレヒラーの 文章はライヘンシュペルガー版からのものと思われる。

\section{2.『教本』における寸法決定方法}

教会堂にかかわる大小の寸法は，まず建物全体に関す る大きな寸法を決定し，ここから建築部分の小さな寸法 を導出するという順序をとる。すなわち，最初に教会堂 の内陣の内法幅がとられ"1), これを基準として，これと の簡明な比によって内陣の長さ, 高さ，壁厚や，身廊の 幅, 長さ, 高さ等が決められる。つぎに，決定された内 陣の壁厚もとづいて正方形がとられ，この正方形を用い て窓の方立てやアーチの迫石等の建築部分のテンプレー 卜が決定される。すなわち, 内陣内法幅というマク口・ モデュールから内陣壁厚というミクロ・モデュールを導

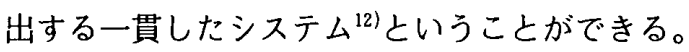

以下にあげたレヒラーの言葉は, 内陣の壁厚から建築 部分の導出の過程と, 正方形を用いた大小二種類のテン プレートの決定方法とを内容とする，「指針」とも言う べき䇢所である。ここでは便宜上これを三つの段落 (A， B， C）に区切って示す。

「(A) 小さいものであろうと大きいものであろうと, 内陣の 壁厚をとりなさい。そのとき，互いに貫通する二つの正方形 を描きなさい。そのなかの大きな正方形内に，あなたはすべ

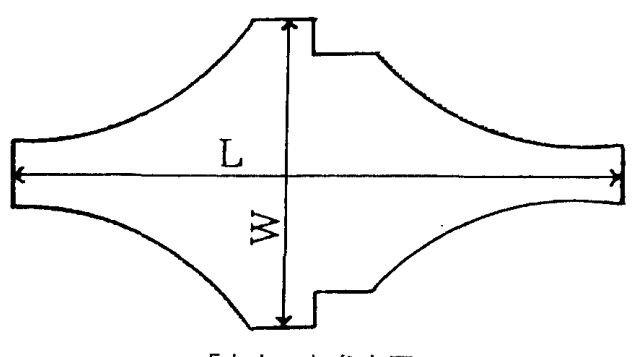

「方立て」参考図 
てのテンプレートを見出すであろう。ちょうどあなたがこの 本のなかに描かれたそれらを見出すように。あなたがより簡 単に理解できるように, 私はあなたのために［それらを]本 のなかに文章に続いて描いだ。

（B）そのとき内陣の壁厚を三つの部分に分けなさい。これ らの部分のうちから一つをとり，同じ部分を再び七つの部分 に分割しなさい。これが, あらゆる建物のための正しいく老 いた方立て〉である。しかし，もしあなたがく若い方立て〉 をつくることを望むなら一それはしばしば用いられるのであ るが一，そのときは 7 部分から 5 部分を残して 2 部分をとり 去りなさい。この 5 部分がく若い方立て〉を示し，これをあ なたはたやすく理解するであろう。このように，〈老いた方 立て〉は 7 部分をもち, 〈若い方立て〉は 5 部分をもつ。を .してく若い方立て〉はく老いた方立て〉からとり出される。 （C）あなたが正方形を 3 部分に分割したよき，四つの頂点 の上を大きな正方形が越えるようにもう一つの正方形を描 き, [そして] もう一度,一つの上を他の一つが越えるよう にすると, あなたは幅と長さを得るであろう ${ }^{13)}$ 。」(角括弧内 はシェルビーによる補足)

さらに，（C）の補足となるようなつぎの文章がある。 「あなたはここに考えをまた見出すであろう。瓦いを通る三 つの正方形を描きなさい。こうしてあなたは長さと幅を見出 すであろうし、これが, 人が利用するほとんどすべてのテン プレートがそこから出てくる正しい平面図である。私はあな たにこれらの指示を一つ以上の方法で与えた。というのも, もしある徒弟がこれを受けとることを望んだならば，そのと き，あなたは彼に一つ以上の方法で一つのことを教え，そし て正しい平面図を彼に示すことができる14)。」

これに加えて，レヒラーの他の指示や，彼自身による 図および図に書き込まれた言葉を参照することによっ て，上記の指示の内容をより明確にすることができる。 とくに, 今回検討の対象とする二つの図 (図一1，3）は, 「一つ以上の方法で与え」られたテンプレートの設定方 法を典型的に示していると考えられる。図一1 から順に とりあげ，指示の意味するところを考えたい。

\section{3.「R-L図式」による方法}

上述の段落 $\mathrm{A}$ からCまでを図示しているのが図一1で ある。指示文を図と関連させて要約するとつぎのように なる。.まず内陣の壁厚に等しい辺長をもつ正方形をつく り，これと同大の正方形を $45^{\circ}$ 傾けて重ねて八芒星形と する(段落 A)。この八芒星形を構成する正方形の辺を 三等分して，もとの正方形のなかに九つに分割された小

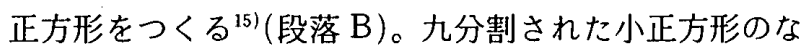
かの中央の小正方形の辺の中点を結んで内接正方形をつ くり，この内接正方形のなかにさらに内接正方形をつ くって合計三うの入れ子になった正方形を描く（段落 C)。図一1-(1) として示されているのがここまで指示 である。この図一1-(1) の中央の小正方形の部分のみ をとりだして拉大して描いたものが図一1-( 2 ) である。 図一1-(2) に描かれた三つの正方形の展開方法は, 口
リツァーが「ピナクルに関する小冊子』において開示し た方法一「正方形のロリツァー的展開」と名づけられる 方法 ${ }^{16)}$ 一である。

つぎに図一1-(2) において，指示文でおのおの<老 いた方立て〉と〈若い方立て〉とよばれる大小二つの方 立ての設計方法が指示される ${ }^{17)} 。$ ヘヒトは，図-1-(1) における九分割された小正方形の一つである中央の小正 方形が, 図一1-(1) の下部に描かれた 12 の目盛り長さ に等しい大きさをもつといい, また，図一1-(1) の中 央の小正方形がそのまま図一1-(2) における最大正方 形として描かれている（図一1-(2) における最大正方 形の辺長が 12 である)，とする18)。しかし段落 B の文章 においてレヒラー自身が，壁厚の $1 / 3$ がく老いた方立 て>(図一1-(2) に描かれている) の長さになるという のであるから, 図一1-(2) は, 図-1-(1) 内の中央の 小正方形のなかに順次内接した正方形のうちの最内から

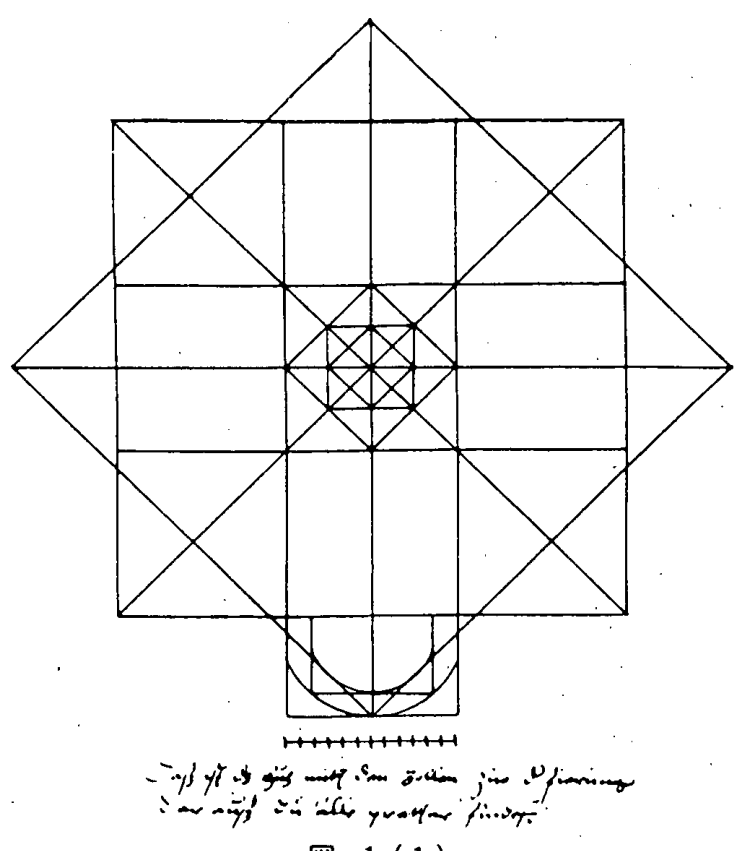

図-1-(1)

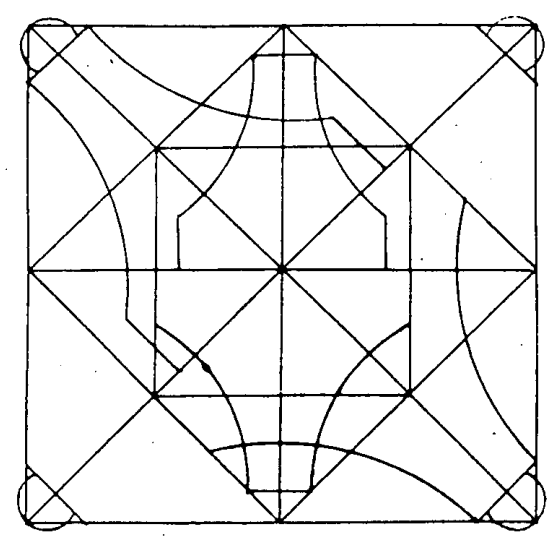

㘣-1-(2)

図一1八芒星形と「R-L 図式」に上る方立ての設計法 ( $\mathrm{K}$. Hecht, Maß und Zahl in der gotischen Baukunst より) 
の三つが拡大されて描かれているとみなければならな W。

〈老いた方立て〉からく若い方立て〉を得る方法一 シェルビーーマークのいう「一つの尺度からもう一つの 尺度に移しかえるための公式191一が，指示文のなかで は「7 部分」と「5 部分」という言葉で表わされている (段落 B)。これはく老いた方立て>の長さの $5 / 7$ をく若 い方立て〉の長さとする数的表現，あるいはく老いた方 立て〉と〈若い方立て〉の長さを $7: 5$ の比率で示す数 此的表現である。いずれにしてもこれらは算術的な記述 である。しかしこれは「ものさし」の值によって指示さ れる大きさではなく，相互の関係できめられる。

したがって，上記の段落Aにおける「すべてのテンプ レート」とは, あらゆる種類のテンプレートを意味する とともに，またそれらがく老いた〉とく若い〉という二 つの大きさをとる場合であることを意味していると考え られるのである。

$7: 5$ という比率で言及された図-1-(2) の<老いた 方立て>の長さと<若い方立て>の長さ（おのおのを $L_{1}, L_{2}$ とする, 参考図参照) に関して, ヘヒトはいさ さか煩雑な分析を試みているが20)， $L_{1}$ は最大正方形の 対角線長として, そして $L_{2}$ は第二正方形の対角線長 $(=$ 最大正方形の辺長) としてとられている, すなわち, 幾 何学的な無理量比が簡明な整数の比 $7: 5$ によってあら わされていると単純化して考えてもさしつかえないであ ろう211。

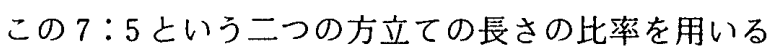
と図-1-(2) の三つの正方形の辺長を表示することが できる。すなわち最大正方形の対角線長が 7 , 同辺長が 5 , 第二正方形の辺長が $7 / 2$, 第三の正方形の辺長（<老い た方立て>の広い方の幅を決定する）が $5 / 2$ である。し たがって，三正方形の三辺は

$5: 7 / 2: 5 / 2$,すなわち

$10: 7: 5$

という連比であらわされる長さをもつ。

この連比は, 幾何学的 (量的) には等しい二つの辺比 一最大正方形と第二正方形との辺比および, 第二正方形 と第三正方形との辺比一が，おのおの $10: 7$ と $7: 5$ と いう二つの比によってあらわされていることを示してお り，また「「リツァー的展開」する二つの正方形間の 辺長の比率が $7: 5$ に加え $10: 7$ という比でもあらわさ れうることをも明らかにしている。「正方形のロリッァー 的展開」を示す図式自体は, 図形というかたちで, 無限 に連鎖する内接正方形の展開を示唆するが22)，上述の連 比は,この「ロリッァー的展開」する正方形間の辺長の 比率が, $10: 7$ と $7: 5$ という二つの比をもち, そのく り返しで展開が連鎖し続けることを示している（…... $14: 10: 7: 5: 7 / 2: \cdots \cdots)$ 。
図一1-(2) を構成する三正方形の辺長に比率を示す 数值を入れて図一 2 を得ることができ，これをここでは 「R (ロリツァー)-L (レヒラー) 図式」と名づける。 図一1-(2) に示された大小二つの方立ての大きさは, 逆にいえば,「R-L 図式」によって決定されるともい えようか。

なお，大きな方立ての広い方の幅を $W_{1}$, 小さな方立 ての広い方の幅を $W_{2}$ (参考図参照) とすると,

$L_{1}: W_{1} \fallingdotseq 2: 1$

$L_{2}: W_{2} \doteqdot 2: 1$

であることは，図一1-( 2 ) 加ら容易に理解できる。

なお，内陣内法幅には実寸法が想定されているので, 内方幅から一定の比率で導出される図-1-(2) も実際 には実寸法をもっている。すなわち図一1-（2）のなか の最大正方形の辺長は，レヒラーが例としてあげた壁厚 の值を三等分して導出される 7 in, 8 in, 9 in, 12 in, 14 in のなかのいずれかを一つとりうるのである ${ }^{23)} 。$

ここから，図一1-(1) の下部の書き込みの文章に一 つの解釈を提示することができる。その書き込みとはつ ぎのようなものである。

「これは、そこからあなたがすべてのテンプレートを見出す 正方形のためのインチを伴うシュー (フィート)である」

$\mathrm{Da} B$ ist der schuh mitt den zollen zue $\mathrm{d}(\mathrm{er})$ fierung darauß du alle pretter findest ${ }^{241}$.

「シュー」という言葉は, シュムッテルマイアの『ピ ナクルに関する小冊子」においてもく古いシュー> (alt schuch) とく新しいシュー>(new schuch) というよく 似た表現であらわれる ${ }^{25)}$ 。しかしシュムッテルマイアの いうく古いシュー〉と〈新しいシュー〉とは,「ロリ ツァ一的展開」して得られる二つの正方形の各辺長とい う幾何学的に示される長さ一「基本単位」一をいうので あり，おのおののくシュー>は，具体的な寸法值をもつ ものではなく，また二つの大きさの比率も数比として明 確にあらわされたものではない26)。これに対して上記レ ヒラーの言葉における「シュー」は，これまでの検討か ら，〈老いた〉と〈若い〉という二つの大きさのテンプ レートを設計するための，7：5という比率をもつ「基 本単位」であると理解できよう。また「インチを伴う」 とは, 「具体的な寸法值一上述した 7 in, 8 in, 9 in, 12 in, 14 in のなかのある一つ一をもつ」という意昧に解釈で きる。したがって上述の畫き込みの言葉の全体は，〈す ベてのテンプレートを見出す正方形のための, 1 フット 前後の実寸法をもち $7: 5$ という比であらわされる一組 の「基本単位」としての「シュー」〉と解読できる。また, この書き込みの上部に描かれている 12 の目盛りをもつ 「ものさし」は，八芒星形のなかに分割された小正方形 の辺長, すなわち図一1-(2) の最大正方形の辺長が 12 in一内陣の壁厚が $3 \mathrm{ft}(12$ in $\times 3)$ の場合にあたる一で 


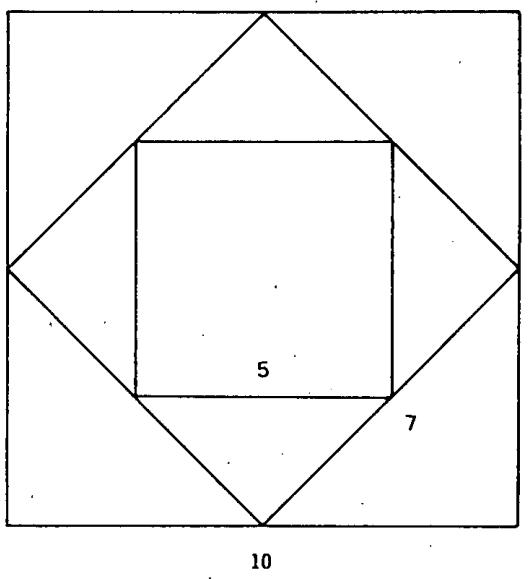

図一2「ロリッァー（R）ーレヒラー（L）図式」(浅野, 谷川)

あることを示すもの，と解粕できよう。

\section{4. 八芒星形と「ものさし」による方法}

図一3にも図一1-（1）と同じく八芒星形が描かれ， これを使ってテンプレートと思われるものが各種描かれ ている。図一3もまた，建築部分のテンプレート決定の 「指針」，ともよぶべき上述のレヒラーの指示一《内陣の 壁厚に等しい辺長をもつ互いに貫通する二つの正方形 (八芒星形) のなかに，あなたはすべてのテンプレート を見出すであろう>一を何らかの方法で示していると思 われるが，それはどのようなものであろうか。両図を見 くらべることから，つぎのことが明らかになる。

八芒星形を描く点で図一 3 は図一1- 1 - 1 ) と同椂であ る。しかし図一 3 においては，九つの小正方形を構成す る分割線が八芒星形内になく, 図一1-（1）にあたる図 が描かれていない。かわりにここには図一1-(1)には ない「ものさし」がとられている。また図一1-(1)では, 下部に二つの半円で描かれたただ一つのテンプレート （後述）がとられるのみであるが，図一3にはさまざま なテンプレートが描かれている点等が巽なる。

＜八芒星形のなかにすべてのテンプレートが見出され る>のであるから，八芒星形をとる図一3においても， 図一1における「R-L 図式」にかわるなんらかの方法 で各種のテンプレートのく老いた〉とく若い〉の二つの 大きさのとり方が指示され，その間の「変換公式」が示 されていると考えるのが妥当である。その「変換公式」 の一つが，テンプレート様の図形が描かれている図一3 の四つの芒形部分（突出した三角形部分）であると考え られる。特に左右の芒形部分に重なる二つの矩形の枠に おいては，三角形に重ねて描かれた矩形枠の長辺（右側 の二重矩形の場合は大きい方の矩形の長辺）が八芒星形 を構成する正方形の辺長の $1 / 3$ の長さをもっているの でここが図一-1-(1) の九つの小正方形のかわりをし ていると推定されるのである。上部の芒形突出部分に描 かれている方立ての場合には，大きな方立ての長さ自体
がそれにあたると思われる。

図一3におけるもう一つの「変換公式」と考えられる のが「ものさし」である。八芒星形の対角線上に中心点 をはさんで左右それぞれに七つの目盛りをもつ「ものさ し」が,ささらにその右上に五つの目盛りをもつ「ものさ し」が描かれている。七つの目盛りをもつ「ものさし」 と五つの目盛りをもつ「ものさし」は同じ実長をもち, かつ，これは八芒星形の正方形の辺長の三分の一に等し い長さでとられていることが図から測りとれるで。した がって七つ目盛りの「ものさし」と五つ目盛りの「もの さし」のおのおの 1 目盛り分の長さは,

$1 / 7: 1 / 5$, すなわち

$5: 7$

の比率となり，七つ目盛りの「ものさし」と五つ目盛り の「ものさし」自体がく若い〉とく老いた＞の関係をも つ。前者を「表尺」, 後者を「裏尺」とよぶことができ よう ${ }^{281}$ 。

芒形突出部分に重なる矩形と「ものさし」がいかにし て一単独で, あるいは相俟って一図一1における「RL図式」の役割を担うのかは, 図一3に描かれた各テン プレートの設計方法を以下個別に検討して行くことに よって明確にされるであろう。

4-1.

図の上部に描かれている大小二つの方立てのテンプ レートから検討を始めたい。

方立てに関する短い言葉が，「表尺」の下につぎのよ うに記されている。

「老いた方立てのテンプレートに7部分, そして若いテンプ

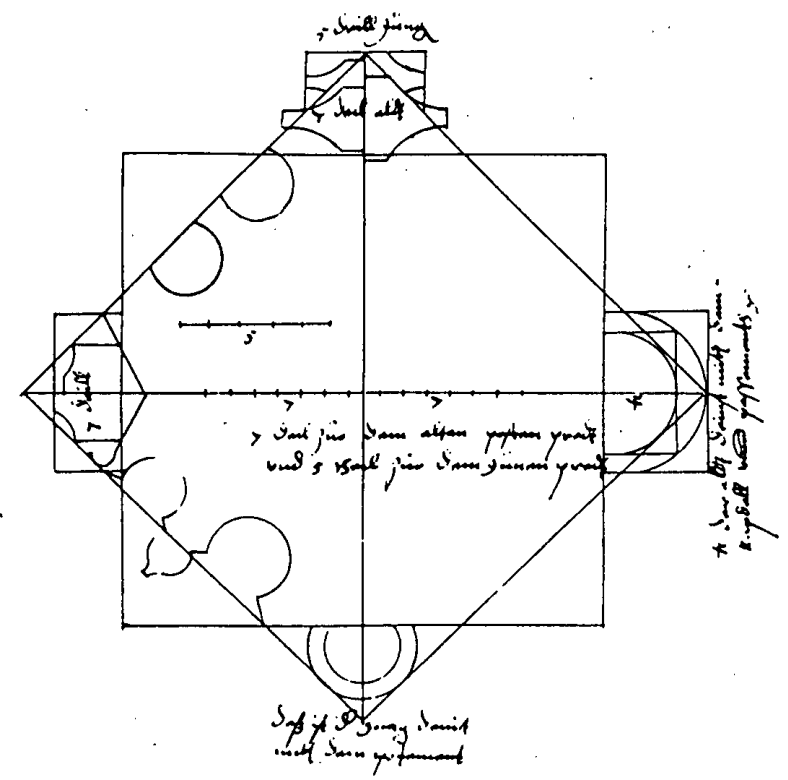

图一3 八芒星形と「ものさし」による方立て (上) とシャフト (右, 下) の設計法

(K. Hecht, Maß und Zahl in der gotischen Baukunst より) 
レートに 5 部分」

7 deil zue dem alten posten predt vnd 5 theil zue dem junen predt

さらに,方立てのテンプレートにも短い書き込みがあり， 小さな方立ての上に

$\lceil 5$ 部分 若い」

5 deill jung,

大きな方立てのなかに

「部分 老いた」

7 deill aldt

とある ${ }^{29\}}$ 。

以上の三つの書き込みとデバイダによる計測から，「7 部分 老いた」とは，大きな方立てが「表尺」で7目盛 り分の長さをもつこと，「5 部分 若い」とは小さな方 立てが同じく「表尺」で 5 目盛り分の長さをもつことを 意味すると解される。したがって，ここではく老いた〉 と〈若い〉という二つの大きさが「表尺」上で $7: 5$ の 比率でとられている。

4-2.

シャフトに関して，レヒラーはつぎのような指示文を 記している。

「私はあなたのために正方形のなかに二つの手順でシャフト を描きたい。老いたものと若いものである。それによってあ なたは，柱頭と柱礎をもつシャフトを決定する方法を知るで あろう。…..私があなたのために以前述べたように，正方形 のなかにシャフトを描きなさい。そして迫元の下の柱頭まで, 柱礎の上にシャフトを立ち上げなさい(30)。」

この指示文に対応する図が，図一 3 の右側と下部の二 か所に描かれた二つのテンプレートと考えられ，図の側 にはそれぞれつぎの書き込みがある。右側のシャフトの 図の側に

「柱頭と柱礎をもつ老いたシャフト」

Der aldt deinst mitt dem kapdall unnd postament

(der aldt deinst mitt dem Kapdell vnnd possament)

また，下部のシャフトの図の側には

「これは柱礎をもつ若いシャフトである」

Das ist der jung deinst mit dem postament

(daß ist $\mathrm{d}(\mathrm{er})$ jung deinst mitt dem postament)

とある31!。ここでも大きなシャフトがく老いた〉という 言葉で，小さなシャフトがく若い〉という言葉で言及さ れている。

〈若いシャフト>の方は「柱礎をもつ」とだけ述べら れているので，小さな弧がシャフトに，大きな弧が柱礎 にあたると考えられる。

く老いたシャフト>の方は「柱頭と柱礎をもつ」とさ れている。<若いシャフト>にならって二つの弧がシャ フトと柱礎を示すと考えれば，二つの弧に外接するよう

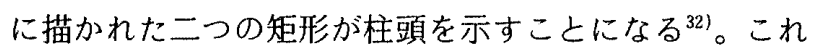
らの大きさはよ゙のように決定されるのであろうか。
〈老いたシャフト>のシャフト径はつぎのようにして 決められていると考えられる。

二つの弧の中心あたりに書き込みの文章と天地を逆に して単独でおかれた数字の「4」のような記号が見える ヘヒトはこれを十字架とみるが33)，シェルビーは，これ を図の側にある書き込み一「柱頭と柱礎をもつ老いた シャフト」一の頭におかれたものと同じ記号であるとし， これらをともに逆さまにされた「4」とみなして，「4」 が「裏尺」での 4 目盛り分の長さを指すと指摘するが, 「ものさし」(「裹尺」) のもつ意味は説明できないとい う ${ }^{34}$ 。本稿ではこの記号を，シェルビーがいうような天 地逆にされた数字の「4」と解积したい。というのも， 「裏尺」で 4 目盛り分の長さをとるとこれがちょうど小 さな弧（シャフト）の径にあたるので，二つの「あ」は シャフト径を示す数值と解読できるからである(「裏尺」) を使うので「4」もひっくりかえされているのであろう か)。

まだ，小さな弧（シャフト）の径を「裏尺」を使って の「4」とみると，大きな弧があらわすく老いたシャフ ト>の柱礎の径をつぎのように考えることができる。す なわち，柱頭のテンプレートを示す小さな矩形と大きな 矩形 ${ }^{351}$ がシャフト亡柱礎のおのおのの弧に外接している とみて，柱礎の径（=大きな矩形の長辺）は，大きな矩 形の長辺長さに等しく，八芒星形を構成する正方形の辺 長の $1 / 3$ ，すなわち「裏尺」でちょうど 5 目盛り分の長 さとなる。仮にこれを「表尺」で表示すると，柱礎の径 すなわち大きな矩形の長さが 7 ，シャフトの径すなわち 小さな矩形の長さは $41 / 2$ あるい 5 になり ${ }^{36)}$ ，大きな矩 形の幅（八芒星形の正方形辺からの大きな矩形の出）は

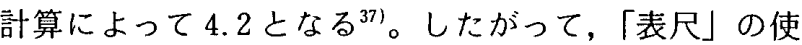
用では天地逆に書かれた「4」を解釈できないことにな る。このように，「す」と「裏尺」を新たに解积しなお すことで，〈老いたシャフト〉にかかわる二つの值一 シャフト径と柱礎の径一を 4 と 5 という簡潔な值で示す ことが可能になる。

〈老いたシャフト>の三つの弧は半円よりも若干長い 弧であるように見えるので，シャフトと柱礎のおのおの の弧の中心は,八芒星形を構成する正方形の辺と,「表尺」 がとられている横軸との交点から右方向にずれたところ にあることになる。まず柱礎の弧の中心に関して，ヘヒ 卜は理由を示さずに，弧の中心が「表尺」で測定して $1 / 2$ 目盛り分外側へずらされているという381。しかしこ れは計算によって求めることができ,それは交点から「裏 尺」での測定で $1 / 2$ 目盛り分右側に出たところである ${ }^{399} 。$

一方シャフトの弧の中心に関しては，シャフトの弧に 外接する小さな矩形の短辺長さの厳密な值を求めること ができないため，中心を確定することはできない。これ についてシェルビーは，図一3の<若いシャフト〉は二 
つの弧の中心が一致しないので正しく描かれたものでは なく，図一1-(2) の下部に描かれた二重の弧（中心が 一致する）が図一 3 のこの〈若いシャフト>のテンプ

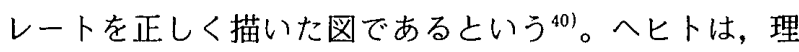
由を述べないが，シャフトと柱礎の中心は「表尺」で 1 目盛り分外側にずれた同一箇所に位置するという ${ }^{411} 。 し$ かし図から判断するかぎり，この説は正しいと思われな い。というのも，ディバイダで測定すると，小さな矩形 の出は「裹尺」で測ってほぼ $21 / 2$ 目盛り分になり,シャ フトの中心は八芒星形を構成する大正方形の辺から「裏 尺」でおよそ $1 / 2$ 目盛り分出たところになって，柱礎の 中心に一致するか, それにごく近いところに位置すると 判断されるからである。

〈老いたシャフト>が「裹尺」で決定されているとみ なせることから，図一-3の下部に描かれたく若いシャフ ト>の寸法は「表尺」によって求められると推定できる。 なぜなら，「裏尺」と「表尺」の関係から，〈老いたシャ フト>の「裏尺」での寸法值をそのまま「表尺」に適用 することによって，〈若いシャフト>の寸法值が出るか らである。実際わずかなずれがあるものの，「表尺」で 測定值でシャフト径が 4 目盛り分, 柱礎の径が 5 目盛り 分の長さである。

すなわち，図一3の二つのシャフトのテンプレートに おいては，「裏尺」と「表尺」の同じ值を適用してく老 いたシャフト〉とく若いシャフト>が描き分けられてい るのである。

$4-3$.

図一3 左図のテンプレートに関して，レヒラーはいか なる説明もしていない。シェルビーの解釈にしたがって これを脇柱のテンプレートとみると ${ }^{42)}$, 図のなかの「7 部分」(7 deill $\left.{ }^{43)}\right)$ という書き込みは, 芒形部分に重な る脇柱が「表尺」の測定值で 7 目盛り分の長さをもつこ とを示すと思われる。しかしこの図が脇柱の形態をどの ように示しているのかが不明であるので，さしあたりこ れ以上の言及は避ける。

また，図一3の上部の図と左図のあいだ，および左図 と下部の図のあいだに描かれた形態に対してもレヒラー はなにも説明しない。ピアの構成物の一部としての 4 本 の溝と 1 本の小さなシャフトを表わしているという説明 があり ${ }^{44)}$, 脇柱のテンプレートと一続きのものであると 思われるが，詳細は不明である。

\section{5. 結}

レヒラーの『教本』における二つの図（図一1 と図一 3）およびこれにかかわるレヒラーの説明文において， 各種の建築部分のテンプレートはく老いた〉とく若い〉 という言葉で形容される二つの大きさで設定することを
要請され，これらの二つの大きさは 7:5という比率で 算術的に言及される。また, 〈老いた〉テンプレートと 〈若い〉テンプレートは, 教会堂の内陣の内法幅（実寸 法をもつ）から一定の比率でとられた内陣壁厚を辺長と する正方形から構成される八芒星形を用いて設定され る。

レヒラーが詳述しない二つの大きさのテンプレートの 決定方法に関して, 今回検討したことをまとめると以下 のようになる。

(1) 〈老いた〉と〈若い〉という二つのテンプレート の第一の設定方法は，八芒星形を構成する正方形の辺を 三等分してつくられた 9 個の小正方形の一つを「正方形 のロリッァー的展開」し，こうして得た順次内接する三 正方形からなる図式を用いるものである。このような図 式の三正方形のおのおのの辺長は $10: 7: 5$ の比率をも ち,これを「R-L図式」と名づける。

（2）第二の設定方法は，八芒星形の芒形部分と「もの さし」を用いる方法である。これはさらにつぎの二つの 方法に区別される。

(3) その一つが,一つの「ものさし」の上で 7 目盛り 分と 5 目盛り分の大きさをとる方法である。

（4）他の一つが, 7:5の比率の目盛りをもつ二つの 「ものさし」一「裏尺」と「表尺」一を使い分ける，す なわち二つの「ものさし」上で同じ值をとる方法である。 （５）レヒラーの幾何図形一八芒星形と「R-L 図式」 一は実寸法が想定されている。これに比して，シュムッ テルマイアのくシュー〉(〈古いシュー〉とく新しい シュー>)は, 面積比 $2: 1$ の二つの正方形の二つの边長 の比 $\sqrt{2}: 1$ という比率をもつ幾何図形的（量的）な「基 本単位」であった。

ブドンの定義によると，シュムッテルマイアの くシュー>は「比例」であり, レヒラーの「ロリッァー 的展開された正方形」は「尺度」ということができる ${ }^{45) 。 ~}$

\section{注}

1) レヒラーの経歴に関してはU. Thieme and F. Becker eds., Allgemeines Lexikon der Bildenden Künstler von der Antike bis zur Gegenwart, 37 vols., E. A. Seemann Verlag, 1907-50に簡綤に記されている。

2) 個々の石材に刮形 (molding) や輪郭 (profile) の形を 写しとるために使用する型板。

3) Lon R. Shelby, Gothic Design Techniques, The FifteenthCentury Design Booklets of Mathes Roriczer and Hanns Schmuttermayer, Southern Illinois U. P., 1977, p. 40 (前 川道郎・谷川康信共訳,「ゴシック建築の設計術」, 中央 公論美術出版, 1990 年参照。

4) Lon R. Shelby and Robert Mark, "Late Gothic Structural Design in the 'Instruction' of Lorenz Lechler," Architectura Vol. 9, No.2, 1971.

5）しかしシェルビーは，これよりあとで出版した注 3 にあ 
げた本のなかで（p.127），フォイヒトによるレヒラーの 複製を唯一のものであると述べており，複製の経緯は明 確とはいえない。

6) Shelby and Mark, op. cit., p.114.

7) Lon R. Shelby, “Mediaeval Masons' Templates, ” Journal of the S.A.H., 30, 1971.

8) Konrad Hecht, Maß und Zahl in der gotischen Baukunst, Georg Olms Verlag, 1979.

9) Shelby, “Mediaeval Masons' Templates,” p. 152.

10) Paul Frankl, The Gothic, Literary Sources and Interpretations through Eight Centuries, Princeton, 1960.

11）シェルビーーマークによると, 内陣の内接幅としてレヒ ラーは20ft（フィート，シュー, Schuech）あるいは 30 $\mathrm{ft}$ を推奖するが, 設計者の好みのいかなる幅をとっても よいという。(Shelby and Mark, op. cit., p.117.)

12) シェルビーーマークは, 内陣内法幅を macro-module, 内 陣壁愿を micro-module とよぶ (Shelby and Mark, op. cit., pp. 117 119)。

13) Shelby, "Mediaeval Masons' Templates," pp. 147 148, (Wf. 276*, fol. 44-44 ${ }^{\mathrm{V}}$ (Reichensperger, p. 135)); Hecht, op. cit., p. 185. 原文は省略。

14) Shelby, “Mediaeval Masons' Templates," p. 152, (Wf. 276*，fol.45 (Reichensperger, p.137)) 原文は省 略。

15）ヘヒトとシェルビーーマークは壁厚に関し，つぎのような ことを明らかにしている。すなわち、レヒララーは内陣の 内法幅と壁厚の比として $10: 1$ を推奖し, 壁厚が $2 \mathrm{ft}$ で 良質の石材を用いるときはここから 3 in (インチ, Zoll) を诚じ，弱い石の場合は 3 in を加えてもよいという。し たがって, 内陣内法幅が $20 \mathrm{ft}$ のき，壁厚は内法幅を 10 等分した $2 \mathrm{ft}$, これに 3 in増诚した $1 \mathrm{ft} 9$ in と $2 \mathrm{ft} 3$ in になる。内陣内法幅が $30 \mathrm{ft}$ のときは，これ 10 等分して 壁厚 $3 \mathrm{ft}$ が出る。またこれらと別に, 軒蛇腹の上部に達 する壁の厚さとして $3 \mathrm{ft} 6$ in を指示する。これらの壁厚 の寸法（=八芒星形を構成する正方形の辺長）はすべて 3 で割り切れるので, 小正方形への分割までを考慮に入 れた実寸法であることがわかる。(Hecht，op. cit.， p. 179, 187 ; Shelby and Mark, op. cit., pp. 118 119.)

16) 一つの正方形の各辺の中点をむすんで面積が $1 / 2$ の内接 正方形をつくり, 同様にしてさらにもう一つの内接正方 形をつくる。このようにして得られる三つの正方形の展 開方法 (さらにそれ以上の展開をも示唆する) を「正方 形のロリツァー的展開」と定義する。(拙稿,「ロリツァー とシュムッテルマイアのピナクルの設計法」, 日本建築学 会計画系論文報告集，第 433 号，1992 年 3 月。)

17）大小二つの方立てを指示する理由として，レヒラーは使 用する石の質あるいは石材の産出状況をあげて，つぎの ようにいう。「もしそれが良質のものであれば構成寸法 (dimension) は短縮され, 低質のものであれば寸法は 大きくされなければならない。」(Shelby and Mark, op. cit., p. 115.)

「前の時代の人びとは十分な石材をもっていたので大きな 交差りブをもっていたが，現在ではより経済的に使用す るため，小さな交差りブを使わなければならない。」 (Shelby, “Mediaeval Masons' Templates," p. 150.)

18) Hecht, op. cit., p. 188
19) Shelby and Mark, op. cit., p. 115.

20) ヘヒトは, 図一1-(2) の下端にある 12 目盛りの「もの さし」にもとづき，図-1-(2) の最大の正方形の辺長を 12 とし（前述したようにこの辺長を 12 とみるのは正し くないと思われるが，ここには関係しない)，図一1-(1) のく老いた方立て〉の長さを、テンプレートの両端につ けられた丸い出張りの大きさを引いて示し $(12 \sqrt{2}-21 / 4$ $=14.7205)$, またく若い方立て>の長さを, 正方形の隅 角部分の空きの大きさを引いて計算して $\left(12-11 \frac{1}{2}=\right.$ 10.5000) 比較する。ここにおいても，二つのテンプレー 卜の長さの比は, $14.7205: 10.5000=7: 4.9930 \fallingdotseq 7: 5$ であることが証明されるという。(Hecht，op. cit. pp. 188 190.)

なお，算術的な方法とあわせて幾何図形による方法が用 いられた理由の一つに，図一1-(2) の最大正方形の辺長 を7等分することの困難性があげられている。(Hecht, op. cit., pp.187〜188. ) たとえば上記（注 15）の最大正 方形辺長の五つの実寸法のいすれをも 7 で割ることは難 しい。

21） <1025 年頃に, ケルンのラギンボルドゥスとリエージュ のラドルフスという二人の司教座聖堂学校出身者の間で 取り交わされた数学に関する八通の書簡中の問題におい て, 彼らは, ある正方形の対角線は，これの二倍の面積 を持つ大きな正方形の辺長に等しくなることを知ってい たにもかかわらず，この二つの正方形の辺の長さの比が 17/12（ラギンボルドゥスの比）あるいは7/5（ラドルフ スの比）のような整数比では表わしえないことに気つい ていなかった。実際にはこの両辺は非通約量であり，し たがって無理数比一この場合は $\sqrt{2} / 1$ 一でしか表わすこ とができないのにである。>(E.グラント，横山正彦訳， 「中世の自然学」, みすず書房, 1982 年。)

しかし逆に考えれば，これらの二正方形の辺長比は, 17/12 あるいは $7 / 5$ という整数比（他のいかなる数の組 み合わせでもない）で置きかえられていたことになる。 7/5よりも近似であるにもかかわらず，レヒラーにおい て17/12が採用されなかったのは，これが煩頊であった ためと考えられる。

22）前揭拙稿。

23）注 15 にあげた壁厚を 3 で割ると, $1 \mathrm{ft} 9 \mathrm{in} / 3=7 \mathrm{in,} 2$ $\mathrm{ft} / 3=8$ in, $2 \mathrm{ft} 3 \mathrm{in} / 3=9$ in, $3 \mathrm{ft} / 3=12$ in, $3 \mathrm{ft} 6$ in $/ 3=$ 14 inとなる。

24) Hecht, op. cit., p. 188.

25）大きなくシュー>に対し、レヒラーもシュムッテルマイ アもともに“alt schuch”とよぶが,小さな方のくシュー〉 に対しては，シュムッテルマイアは“new schuch”（〈新 しいシュー〉), レヒラーは“jung schuch”(く若い シュー〉)とよぶ。したがってこれに呼応して、シュムッ テルマイアの “alt schuch”を〈古いシュー>, レヒラー のそれをく老いたシュー〉とよび分ける。

26) 前揭拙稿。

27）ヘヒトもつぎのようにいう。「7 単位は正方形の辺長の三 分の一から出てくる。」(Hecht, op. cit., p. 186.)

28）矩尺にあっては,「表尺」を $\sqrt{2}$ 倍したものが「裏尺」で ある。図一1において諗められたように，レヒラーは， $\sqrt{2}: 1$ の比率で表現される幾何学的な二つの長さを $7: 5$ でホしたので、このようなよび方も妥当であろう。 
29) Hecht, op. cit., p. 186.

30) Shelby, “Mediaeval Masons' Templates," p.151, (Wf. 276*, fol. $44^{\mathrm{V}}$ (Reichensperger, pp. $135-136$ )); Hecht, op. cit., p. 195. 原文は省略。

31）原文のうち括弧のないものはShelby, “Mediaeval Masons' Templates," p.151, (Wf. 276*, fol. 44 (Reichensperger, pp. 135 136)), 括弧内は Hecht, op. cit., p. 195 による。

32) Shelby, "Mediaeval Masons' Templates," pp.151 152）も同様の解釉をしている。”このく老いたシャフト〉 の図はロリッァーの「平面図」と同じく，多くの切断面 を一つの図に重ねて描いたものである（前揭拙稿参照）。

33) Hecht, op. cit., p. 195.

34) Shelby, "Mediaeval Masons' Templates," p. 151.

35）「正方形のなかにシャフトを描きなさい」という図-3に 対するレヒラーの指示があるように，シャフトの弧が描 かれる際に正方形を描くことが要請されており，この矩 形は正方形の一部であると思われる。

36）測定の際の起点のとり方によって, どちらとも解釈でき る。

37）八芒星形の正方形の辺長が $7 \times 3=21$, 八芒星形の対角線 長が $21 \times 7 / 5=29.4$ ，したがって大きな矩形の出は（29.4
$-21) / 2=4.2$ 。

38) Hecht, op. cit., pp. 195 196.

39）柱礎の弧の中心を「裏尺」を使って計算すると，八芒星 形の大正方形の辺長が $5 \times 3=15$, 八芒星形の対角線長が $15 \times 7 / 5=21$ ，よって八芒星形の芒の頂点に一致する大き な矩形の出 (短辺長) は $(21-15) / 2=3,3-21 / 2$ (柱礎 の弧の半径) $=1 / 2$ (目盛り分) となる。

40) Shelby, “Mediaeval Masons' Templates," p.151.

41) Hecht, op. cit., p. 195.

42) Shelby, “Mediaeval Masons' Templates,” p. 152.

43）筆者による図一3からの読みとり。

44) Shelby, “Mediaeval Masons' Templates,” p. 152.

45）全体が一つの閉じた体系であると見なされる一つの空間 のなかで, ある一要素を別の要素と照合することによっ て計測が行われるのが「比例」(プロポルシオン)であり， 一つの建物の全体あるいはその部分をこの建物の外にあ る一要素と照合して計測するということを想定させるも のが「尺度」(エシェル)である。(P. ブドン著, 中村貴 志訳, 「建築空間 [尺度について]」, 鹿島出版会, 1978 年。)

(1992 年 4 月 24 日原稿受理, 1992 年 12 月 3 日採用决定) 